\title{
Role of Microbial Flora and Probiotics in Host Immune Homeostasis
}

\author{
Pratibha Mishra $^{1^{*}}$, Sunil Kumar Mishra ${ }^{2}$ \\ ${ }^{1}$ Department of Pharmacy, Dr B R Ambedkar University, Agra. \\ ${ }^{2}$ Department of Pharmacy, S.N. Medical College, Agra.
}

\begin{tabular}{|c|c|}
\hline ARTICLE INFO & ABSTRACT \\
\hline $\begin{array}{l}\text { Article history: } \\
\text { Received on: } 06 / 10 / 2017 \\
\text { Accepted on: } 18 / 04 / 2018 \\
\text { Available online: } 31 / 10 / 2018\end{array}$ & $\begin{array}{l}\text { Microbiota refers to an abundant and diverse population of bacteria, archaea, fungi and other microbial eukaryotic } \\
\text { species reside in the gastrointestinal tracts and other body sites exposed to the environment. A Microbial symbiosis } \\
\text { was established between the host and the microbial flora. The host provides a favorable environment for the } \\
\text { colonization of microbiota and in respect to this microbial flora actively participates in the metabolic process of } \\
\text { the host, synthesis of vitamins, production of nutrients, enhancement of mucosal barrier functions, and also inhibits }\end{array}$ \\
\hline $\begin{array}{l}\text { Key words: } \\
\text { Microbiota, } \\
\text { Microbial symbiosis, } \\
\text { Immunomodulatory, } \\
\text { Autoimmune disorders, } \\
\text { Immune homeostasis, } \\
\text { Probiotics. }\end{array}$ & $\begin{array}{l}\text { the colonization of pathogens. In addition to this Microbial flora have the fundamental role in the development and } \\
\text { establishment of host immune homeostasis. Microbiota induces the protective responses against the pathogens and } \\
\text { modulates the regulatory pathways in such way to develop the tolerance against the innocuous antigens. Alteration } \\
\text { in the composition of microbial flora results in many gastrointestinal diseases including obesity, inflammatory bowel } \\
\text { diseases, systemic infections, autoimmune disorders, and even colon cancers. These features of microbiota focus the } \\
\text { research on their composition and a wide range of their functional aspects. The objective of this review is to explore } \\
\text { the symbiotic relationship between intestinal microbiota and host, the contribution of the microbial flora in host } \\
\text { immune homeostasis as well as the concept of 'probiotics' as a possible therapeutic approach to restore the normal gut } \\
\text { microbial flora and host immune homeostasis. }\end{array}$ \\
\hline
\end{tabular}

\section{GENERAL ACCEPTANCE AND INTEREST}

The gut-associated lymphoid tissue is the largest immunity component, which serves as the major site of lymphocyte to contact with antigens in the daily course of life. Approximately, trillions of bacteria are associated with host gastrointestinal tract. This wide range of the microbial community (gut microbiota) was coevolved in a symbiotic manner with the host intestinal mucosa in such a way that the indigenous microbiota is essential for the gut homeostasis and establishment of innate and adaptive immunity of the host.

Current literature survey reveals that the gut microbial flora participates in a number of important functions including, exchange of the nutrients and metabolic waste, metabolism of the carbohydrates to generate the short-chain fatty acids (SCFAs), produce anti-inflammatory proteins, antioxidants, vitamins and as immunomodulatory. In addition, gut microbiota act as a safeguard

${ }^{*}$ Corresponding Author

Pratibha Mishra, Department of Pharmacy, Dr B R Ambedkar

University, Agra, Uttar Pradesh - 282002, India.

E-mail:mishra_prati@yahoo.co.in by developing a barrier to prevent direct interaction of pathogens with gut mucosal cells and also compete with pathogens for nutrients and site for their colonization. Gut microbiota by interacting with the intestinal epithelial cells induces the secretion of the antimicrobial peptides and potentially contributes to the development and establishment of the immune system (Vieira et al., 2013).

The composition of the balanced microbial flora disrupted from various factors including diet climate, aging, medication (particularly antibiotic consumption), illness, stress, and lifestyle can upset this balance, leading to diarrhea, mucosal inflammation, or other serious illnesses. Predominantly the consumption of antimicrobials and antibiotics are the foremost issue since their oral administration significantly disrupt the ecology of the beneficial microbial flora and create an opportunity for the pathogens to invade to increase the severity previous infections and cause a new infection. Since, antibiotics were designed with an objective to produce a broad spectrum of activity, so as they can be used to treat a wide range of microbial infections. Because of the broad-spectrum impact of antibiotics, their antimicrobial effect is not selective towards the specific pathogenic population, the 
other related members of microbiota are also targeted, and they often leaving a lethal imprint on the gut community long after the antibiotic therapy removed. Long-term therapy with antibiotics also promotes the development of antibiotic-resistant microbial flora. The antibiotic-resistant strains of microbes also serve as a lasting reservoir for resistance genes in the gut microenvironment (De La Cochetière et al., 2008; Brandl et al., 2008). Consequences result by antibiotic therapy includes: (i) Loss of bacterial ligands responsible for the induction of immune responses in the host, (ii) Alterations in the fate of metabolism of metabolites produced by the microbiota and host, (iii) loss of specific bacterial signals involved in the host immune homeostasis, (iv) Imbalance of Ecology of Microbial Flora, (v) Transformation in Immunity (vi) Emergence of Resistance, (vii) Antibiotic-Associated Diarrhea, and (viii) Antibiotic Associated Genitourinary Tract Infection. In the view of above reported serious consequences, medical practitioners advise probiotics (live microorganism - Pharmaceutical Preparations) as an adjuvant with antimicrobial and antibiotic therapies. However, over last few years, the concept of "Probiotics" becomes a new line of therapy in supporting the health benefits and to restore the normal gut microbiota. Nowadays, probiotics are recommended as nutritional adjunct therapies to aid digestion, absorption of nutrients, and restore the dysbiosis of microbial flora. Animal studies data and clinical evidence suggested the effectiveness of the probiotic in the treatment and prevention of acute viral gastroenteritis, postantibiotic associated diarrhea, and inflammatory bowel disease including Crohn's disease, enterocolitis and certain allergic disorders (Table 2) (Vieira et al., 2013).

In this review, authors attempt to explore the symbiotic relationship between gut microbiota and host, with evident scientific literature and express the role of the gut microbiota in the development, establishment, and regulation of the various components of the host immune system, supported with recently well-established scientific findings regarding their direct and indirect mechanisms. Furthermore, authors also discuss the major consequences which may result on the dysbiosis of the microbial flora and the concept of 'probiotics' as a possible therapeutic approach to restore the normal gut microbial flora and host immune homeostasis.

\section{MICROBIAL FLORA}

The gastrointestinal tract of a fetus is sterile. After birth, primarily large numbers of E. coli and Streptococci from the environment as well as mother's oral and cutaneous bacterial floral colonize the gut of an infant. Subsequently, bifidobacteria dominated in Breastfed babies possibly breast milk contains growth factors for these anaerobes (Mishra et al., 2012). While the composition of the microbial flora of formula-fed infants is more diversified and dominated by Enterobacteriaceae, Enterococci, Bacteroids etc. (Rodríguez et al., 2015). Ingestion of solid food, the microbial flora of breastfed infant becomes similar to a formulafed infant. Subsequent to end of the second year of life, the fecal flora resembles that of normal adults (Mishra et al., 2012; Guarner et al., 2003). In general, the ecology of the microbial flora of gut consists of Anaerobes: Bifidobacterium, Clostridium, Bacteroides, Eubacterium, and Aerobes: Escherichia, Enterococcus, Streptococcus, Klebsiella (Shanahan, 2002; Vasiljevic and Shah, 2008).

\section{Cross-feeding Synergism (Syntrophism)}

The diversified ecology of the gut microbial flora is mutually dependent on each other for their nutrition (secondary metabolites), colonization, and removal of their waste materials (Jandhyala et al., 2015). This complex phenomenon of co-dependence existence among the microbiota referred as 'Syntrophism' (Cross-feeding Synergism). Cross-feeding Synergism is a relationship in which both members are benefited in aspects of their nutrition. It is best exemplified with the cross-feeding phenomenon (Figure 1), suppose an organism (A) unable to utilize the complex form of nutrients directly but on its metabolism by other microorganisms (B) can be easily assimilated by the first one (A). In this manner microorganism (A) is dependent on microorganism (B) for its nutrients but simultaneously microorganism (A) helps (B) by blocking the negative feedback-inhibition from its own metabolite (Martín et al., 2013).

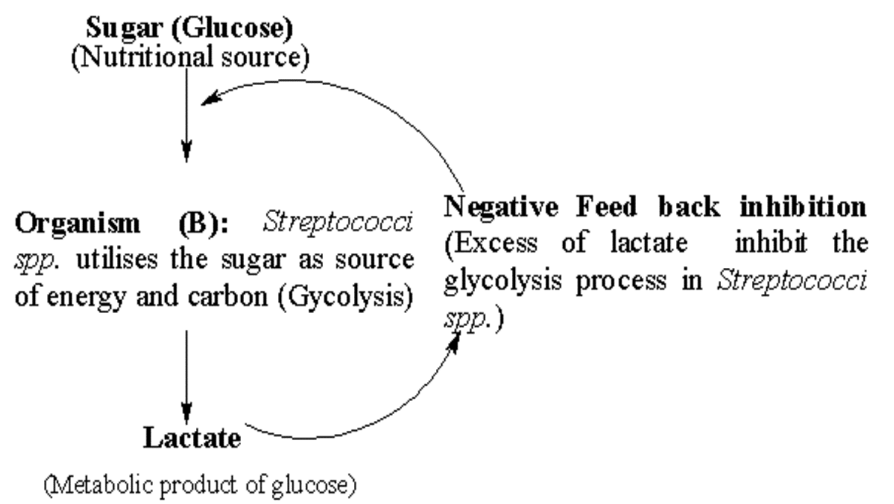

Organism (A): Veillonella spp. uses lactate as source of carbon, since, it is not able to assimilate sugar directly.

\section{Cross-feeding synergism}

Fig. 1: Cross-feeding synergism. Veillonella spp. is not able to assimilate sugar (glucose) directly as a source of energy and carbon so, it is dependent on the glycolysis process carried out by streptococci (streptococci utilize the glucose as a source of carbon and energy and produce lactate as metabolite). On the other hand, an increase in the level of lactate inhibits the glycolysis is a process in streptococci, but further utilization of metabolite lactate by Veillonella spp. prevents this negative feedback inhibition (Wilson, 2004).

For example,

- $\quad$ Production of biomolecules such as amino acids and Vitamins by one flora served as nutrition for other flora. Veillonella spp. produces Vitamin K, which serves as a nutrient for the Prevotella intermedia in the oral cavity. Similarly of Strep. sanguis which provides p-aminobenzoate for species Streptococcus mutans in the oral cavity (Martín et al., 2013).

- Neutralization of substances those are toxic to other flora. For example, plentiful of Lauric acid on the skin is toxic to Propionibacterium acnes but it was metabolized by Malassezia spp., thus enabling the survival of latter organism (Martín et al., 2013). 
- Mucin is an important source of nutrient utilized by the number of bacteria but because of its complex nature (glycoprotein), its breakdown required a wide range of enzymes i.e. sulphatase, sialidase, glycosidase, and protease. Only a few microorganisms possess this set of enzymes, so, that collective cooperation of microorganism is required for the complete degradation of mucin. In gastrointestinal tract Bacteroides spp. by degrading Mucin liberates Sulphate which further serves as a source of energy for the growth of Desuphovibrio spp. (Martín et al., 2013; Rodríguez et al., 2015).

The composition of the microbial flora of the GI tract varies during the life of the individual and also individuals to individuals (Sujatha et al., 2010). Factors can perturb microbial balance includes diet, climate, aging, medication (particularly consumption of the antibiotics/antimicrobials), illness, stress and lifestyle of the individuals. Imbalance in the ecology of microbial flora results diarrhea, mucosal inflammatory disorders, colon cancers or other serious complications (Mishra et al., 2012). Maintenance of an optimal balance of gut microbial flora needed a barrier, created by the friendly bacteria such as gram-positive lactobacilli and bifidobacteria ( $>85 \%$ of total bacteria flora), which inhibit the invasion and colonization of the pathogenic bacteria (Mishra et al., 2012; Sujatha et al., 2010).

\section{MICROBIAL SYMBIOSIS}

The human microbiota participates in the physiology of the host. Trillions of microbes, including bacteria, viruses, archaea, and eukaryotic microbes, colonize the human body (Wang et al., 2017). There is a symbiotic relationship between the host and the gut microbial flora. Microbial flora actively participates in the metabolic process, gut protection and immunological functions of the host. These features of microbiota focus the research on their composition and a wide range of their functional aspects.

\section{Importance of microbial flora}

\section{Synthesis of vitamins}

One of the beneficial effects of the microbial flora is synthesis and release of the vitamins, which further absorbed and utilized as nutrients by their host. For example, in humans, enteric bacteria produce Vitamin $\mathrm{K}$ and Vitamin B12, and lactic acid producing bacteria secrets other B-vitamins (Todar et al., 2012). Vitamins produced by colonic bacteria include biotin, Vitamin K, nicotinic acid, folate, riboflavin, pyridoxine, Vitamin $\mathrm{B} 12$, and thiamine. Vitamin $\mathrm{K}$ is a coenzyme that is essential for the synthesis of several clotting factors, including Prothrombin-a, deficiency results in delayed clotting and excessive bleeding. A variety of microbes found in the small and large intestines synthesize Menaquinones (Vit. K2), such as Bacteroides spp., e.g. Lenta, Propionibacterium spp., Veillonella spp., Staphylococci, enterobacteria, and enterococci (Table 1).

Table 1: Vitamins produced by the human microbial flora (Wilson et al., 2004).

\begin{tabular}{cc}
\hline Vitamins & Produced by organism \\
\hline Vit. K & Bacteroides spp., Eg. Lenta, propionibacterium spp., Veillonella spp., staphylococci, enterococci, enterobacteria. \\
Vitamin B12 & E. coli, Bifidobacterium spp., Klebsiella spp., Veillonella spp., Fusobacterium spp., Eubacterium spp., Clostridium spp. \\
Folic acid & Bif. Bifidum, Bif. Infantis, bif. Breve, Bif Longum, Ent. Faecalis, E. coli, streptococci. \\
Thiamine & Bifidobacterium spp. \\
Nicotinic acid & Bifidobacterium spp. \\
Pyridoxine & Bifidobacterium spp. \\
Vitamin B2 & E coli, Cit. freundii, K pneumoniae, \\
Biotin & Ecoli, Bifidobacterium spp. \\
\hline
\end{tabular}

\section{Nutrient metabolism}

Microbial flora drives their nutrients from the dietary carbohydrates of the host. Colonic flora such as Bacteroides, Roseburia, Bifidobacterium, Fecalibacterium, and Enterobacteria, utilizes the remain undigested host carbohydrate and ferment them to synthesize the short chain fatty acids (SCFA) including butyrate, propionate, and acetate, which further served as a source of energy (Macfarlane and Macfarlane, 2003). The molar ratios of acetate: propionate: butyrate are 71: 21: 8 (compared with 3: 1: 1 in the colon), demonstrating that considerable quantities of butyrate are utilized by colonocytes. In addition, butyrate can also prevent the building up of the toxic metabolites (by-products) such as D-lactate (Bourriaud et al., 2002).

- Acetates are an important source of energy for a variety of tissues, particularly for cardiac and skeletal muscles and for the brain. The fate of propionate in humans is uncertain.

- The member of microbial flora such as Oxalobacter formigenes, Lactobacillus species, and Bifidobacterium species having the ability to metabolize the oxalate obtained from the carbohydrate metabolism, in this manner decreasing the risk of formation of oxalate stone in the kidney (Sidhu et al., 1998; Magwira et al., 2012).

- The microbiota of genus Bacteroides has been shown to synthesize conjugated linoleic acid (CLA) that is known for antidiabetic, antiatherogenic, antiobesogenic, hypolipidemic and immunomodulatory properties (Baddini Feitoza et al., 2009; Devillard et al., 2007; Devillard et al., 2009). 


\section{Xenobiotic and drug metabolism}

The gut microbiomes are capable to metabolize xenobiotics and drugs. In a recent study carried by Clayton et $a l$., reported that gut microbial metabolite p-cresol can decrease the ability of the liver to metabolize acetaminophen because of competitive inhibition of hepatic sulfotransferase (Clayton et al., 2009). Another interesting example of microbiota involvement in drug metabolism is the deconjugation of the anticancer drug Irinotecan, induced by microbial $\beta$-glucuronidase (Wallace et al., 2010).

\section{Antimicrobial protection}

The commensals microbial flora prevents the multiplication and colonization of pathogenic microorganism by producing toxic metabolites including fatty acids, peroxides, and bacteriocins. In addition, they make a competition with the pathogenic microbes for the attachment sites and for the essential nutrient provided by the host.

Microbial flora and its metabolites have been shown to stimulate pattern recognition receptor (PRR) mediated mechanism for the synthesis of antimicrobial protein (AMP) such as cathelicidins, C-type lectins, and (pro) defensins by the paneth cells of the host (Hooper, 2009; Salzman et al., 2007). The pattern recognition receptor (PRR) family includes the membraneassociated TLRs, C-type lectin receptors (CLRs) such as Dectin-1 and cytosolic nucleotide binding ligand oligomerization domains (NOD) like receptors (NLRs) (Salzman et al., 2007). Microorganism-associated molecular pattern includes various microbial components such as peptidoglycan, LPS, lipid A, flagella and bacterial RNA/DNA, fungal cell wall $\beta$-glucans are mainly responsible for the activation of pattern recognition receptors (PRR) to produce AMP (Takeuchi and Akira, 2010; Carvalho et al., 2012).

Table 2: Major Pharmaceutical probiotics and their clinical benefits (Vieira et al., 2013).

\begin{tabular}{|c|c|c|}
\hline Probiotic & Clinical benefits & Mechanisms of action \\
\hline Culturelle $®$ & $\begin{array}{l}\text { - Prevents rotavirus-related diarrhea in children. } \\
\text { - Reduces the risk of respiratory tract infections in children. } \\
\text { Useful in the prevention of atopic dermatitis in children at high risk of } \\
\text { allergy. }\end{array}$ & $\begin{array}{l}\text { - } \text { Prevention of systemic bacteremia. } \\
\text { - Improvement of intestinal epithelial homeostasis. } \\
\text { - } \text { Attenuation of local \& systemic inflammatory responses. } \\
\text { - } \text { Secretion of anti-inflammatory substances. } \\
\text { - } \text { Local induction of reactive oxygen species. } \\
\text { - } \text { Production of bacteriocin. } \\
\text { - Interference in bacterium-induced signaling pathways. }\end{array}$ \\
\hline Enterogermina ${ }^{\circledR}$ & $\begin{array}{l}\text { - Reduces adverse effect and increases tolerability of Helicobacter pylori } \\
\text { eradication therapy. } \\
\text { - Allergic rhinitis in children. }\end{array}$ & $\begin{array}{l}\text { - Improvement of growth performance and immune response. } \\
\text { - The diminishment of intestinal bacterial overgrowth. } \\
\text { - Antimicrobial and immuno-modulatory activities. }\end{array}$ \\
\hline Florastor ${ }^{\circledR}$ & $\begin{array}{l}\text { - Acute diarrhea. } \\
\text { - } \quad \text { Antibiotic-associated diarrhea. } \\
\text { - } \text { Travelers' diarrhea. } \\
\text { - Inflammatory bowel disease. } \\
\text { - Irritable bowel syndrome. } \\
\text { - HIV/AIDS-associated diarrhea. } \\
\text { - Reduction of side effects of H. pylori treatment. }\end{array}$ & $\begin{array}{l}\text { - Antitoxin effects. } \\
\text { - } \text { Trophic effects on enterocytes. } \\
\text { - } \text { Anti-inflammatory effects. } \\
\text { - Enhancement of immune response. } \\
\text { - } \text { Detoxification of bacterial toxins. } \\
\text { - } \text { Binding to and elimination of pathogenic bacteria. } \\
\text { - } \text { Anterference in bacterium-induced signaling pathways. } \\
\text { - Interference in bacterial motility. }\end{array}$ \\
\hline Miyarisan $₫$ & $\begin{array}{l}\text { - Antibiotic-associated diarrhea. } \\
\text { - Reduction of side effects of H. pylori treatment. }\end{array}$ & $\begin{array}{l}\text { - Normalization of intestinal microbiota. } \\
\text { - Antimicrobial effects. } \\
\text { - } \text { Butyrate production. }\end{array}$ \\
\hline Mutaflor $(\mathbb{R}$ & $\begin{array}{l}\text { - Inflammatory bowel disease. } \\
\text { - } \text { Acute diarrhea. } \\
\text { - } \quad \text { Chronic constipation. } \\
\text { - Irritable bowel syndrome. }\end{array}$ & $\begin{array}{l}\text { - } \text { Production of colicines. } \\
\text { - } \text { Adhesin associated with colonization. } \\
\text { - } \text { Resistance to colonization by pathogens. } \\
\text { Effects on permeability. }\end{array}$ \\
\hline VSL\#3® & $\begin{array}{l}\text { - Inflammatory bowel disease. } \\
\text { - } \quad \text { Pouchitis. } \\
\text { - Irritable bowel syndrome. }\end{array}$ & $\begin{array}{l}\text { - Enhancement of immune response/anti-inflammatory effects. } \\
\text { - Enhancement of mucosal host defense. } \\
\text { - Reinforcement of barrier function. } \\
\text { - } \quad \text { Reduction of angiogenesis-promoting growth factors. } \\
\text { - }\end{array}$ \\
\hline
\end{tabular}

Interaction of PRR-MAMP (pattern recognition receptor-Microbe Associated Molecular Patterns) results in the activation of a number of signaling pathways which are needed for development and functioning of the mucosal barrier, and production of AMPs, mucin, glycoproteins and IgA (Kim and Ho, 2010). The members of the microbial flora such as Bacteroides thetaiotaomicron and Lactobacillus innocua are involved as a key role to increase the production of the AMP (Cash et al., 2006;
Hooper et al., 2003).

Bacteroides thetaitaomicron induces the expression in Paneth cells for the matrix metalloproteinase, which consequently cleaves prodefensin into active defensins (López-Boado et al., 2000). Lactobacillus species produces lactic acid, which by disrupting the outer membrane of the bacterial cell wall facilitate the antimicrobial activity of host lysozyme (Bourlioux et al., 2002). 


\section{ROLE OF MICROBIOTA IN IMMUNITY}

The fundamental role of the microbiota in host immunity is to induce, establish and regulating the functioning of the immune system. In response to this immune system helps in the establishment of symbiosis between the host and highly diverse and evolving microbes (Belkaid and Hand, 2014). The host immune system-microbiota symbiosis induces the protective response against the pathogens and modulates the regulatory pathways in such way to develop the tolerance against the innocuous antigens (Figure 2). However, overuse of antibiotics for the quick response against pathogens and changes in the diet results in the shifting of the host immune system-microbiota symbiosis, which may further precipitate as a drastic rise in autoimmune responses and inflammatory disorders.

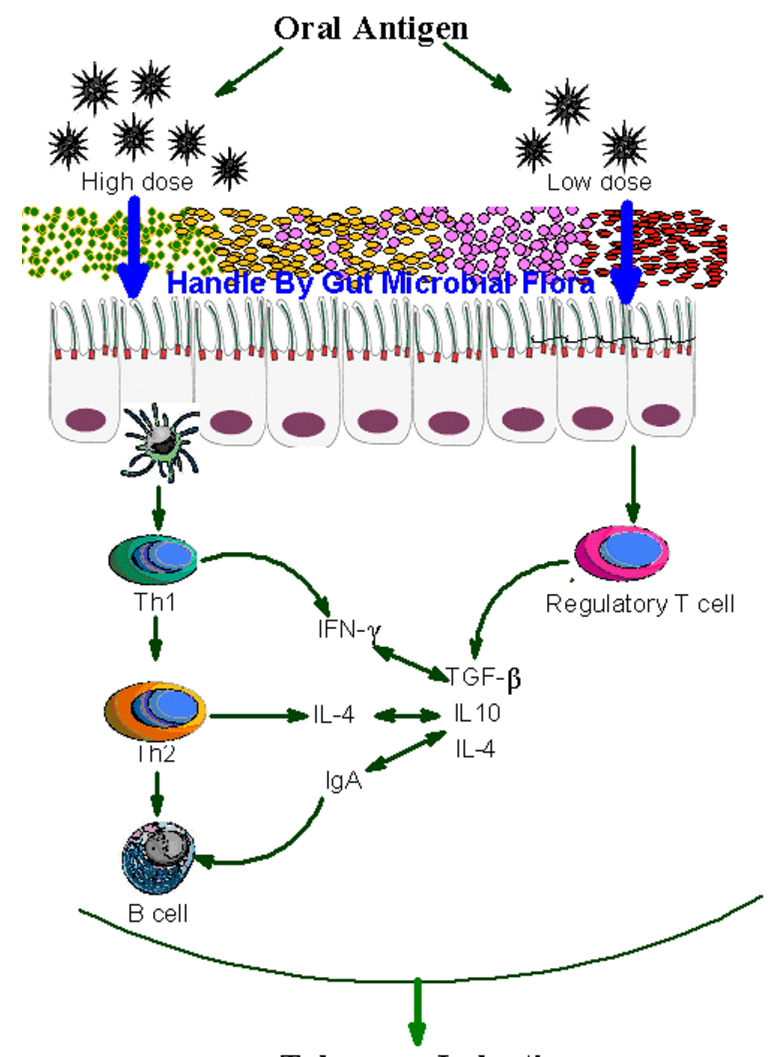

Tolerance Induction

Fig. 2: Mechanism of oral tolerance in relation to the dose of antigen. IFNinterferon; IG-immunoglobulin; IL-interleukin; TGF-transforming growth factor (Isolauri, 2001).

The microbial flora plays a vital role in development as well as the function of the gastrointestinal immune system. But the immune system in response to this regulates the colonization, composition and/or the action of the microbiota. In the healthy individual, this bi-directional responses between the microbial flora and immune system were well balanced. Imbalance in this symbiotic relationship may lead GI diseases, such as inflammatory bowel diseases and extraintestinal disorders including metabolic problems. In this section, the author mainly focuses on the role of the microbial flora in the regulation of the immune responses in perspective to gastro-intestinal homeostasis, host defense, and pathogenesis of GI disease.
Structural development of Gut-Associated Lymphoid Tissues (GALTs)

The mucosal-associated lymphoid tissue (MALT) in GIT develops an immunological barrier and is also termed as gutassociated lymphoid tissue (GALT). The GALT can be categorized into:

- Organized lymphoid tissue. It is composed of mesenteric lymph nodes, Peyer's of patches, microfold (M) cells, dendritic cells (DC) and B cells. The dendritic cells of organized lymphoid work as antigenpresenting cells (APC) that interact with the antigens and communicate with other immune cells such as Native T cells to initiate the immune responses.

- Diffuse lymphoid tissue. It presents in the connective tissue of the lamina propria of the gastrointestinal tract. It is composed of the CD4+ T cells, CD8+ T cells also referred as Intraepithelial lymphocytes (IEL)), B-lymphocytes (memory and plasma cells that produce type A-immunoglobins ( $\operatorname{IgA})$ ), and natural killer cells (NK cells) (Erickson et al., 2000).

The mucosal barrier of the intestinal tract is highly selective and intelligent to distinguish the pathogens and commensal bacteria thereby it preventing the entry of toxic metabolites, antigens and pathogens into systemic circulation (Di Giacinto, 2005). Its hypo-responsiveness towards commensal bacteria and their beneficial nutrients as well as the ingested material is because of the predominant response of the GALT. This hypo-responsiveness is termed as 'tolerance' mediated by both Tand B-cells. In general development of oral tolerance prevents the immunogenic responses but in case of suboptimal oral tolerance hypersensitivity reactions may result against the ingested antigens. For instance, if an individual is not able to tolerate the milk proteins, then a hypersensitivity reaction may result to dairy products. This hypersensitivity reaction often commences with the polarization of either T helper cells-1(Th1) or T helper cells2(Th2) cell (Di Giacinto, 2005; Isolauri et al., 2001).

\section{Development of humoral immune system}

Immune responses are due to the release of specific cytokines to stimulate the native T-helper (Th) cells to turn on either Th1 domination to promote cellular immunity or Th2 domination for humoral immunity (Figure 3). However, if there is an imbalance in release and level of cytokines sustained, then the higher level cytokines induce their respective T-cell pathways to produce immune pathological conditions like atopy, hypersensitivity reactions and chronic inflammation (Leah et al., 2009).

This has been recently accepted that supplementation with probiotic preparations helps to modulate the immune system by restoring microbial flora (Neurath et al., 2002). Probiotic preparations have an ability to modulate the components of an immune response including humoral, cellular or innate immunity (Smith et al., 2007). Recently this has been accepted that specific probiotic strains induce the secretion of specific cytokines thereby they facilitate the development of native T-cells towards a particular immune pathway (Smith et al., 2007).

Germ-free (GF) model was used to evaluate the importance of the microbiota for the establishment of both innate 
and adaptive immunity (Rakoff-Nahoum et al., 2004). Alternate approaches to validate the importance of the microbial flora in immune homeostasis are either with antibiotic treatment or reconstitution of microbiota. These approaches are also implacable for the study of the role of microbiota in autoimmunity since the gut microbial flora not only participates in the local intestinal immune system but also actively involved to influence the systemic immune responses (Mazmanian et al., 2005; Gordon et al., 1966).
Furthermore, the GF animals have the imbalanced development of the GALTs, such as Peyer's patches (PPs) and isolated lymphoid follicles (Bouskra et al., 2008; Kamada et al., 2013). This has been noticed that there are increased number of the immunoglobulin (Ig) E + B cells and decreased numbers of IgA + B cells were found in the PPs of GF mice. Colonization of commensals microbiota in GF mice induces an immune reaction in lymphoid cells clusters referred as germinal centers and increase and development of IgA.

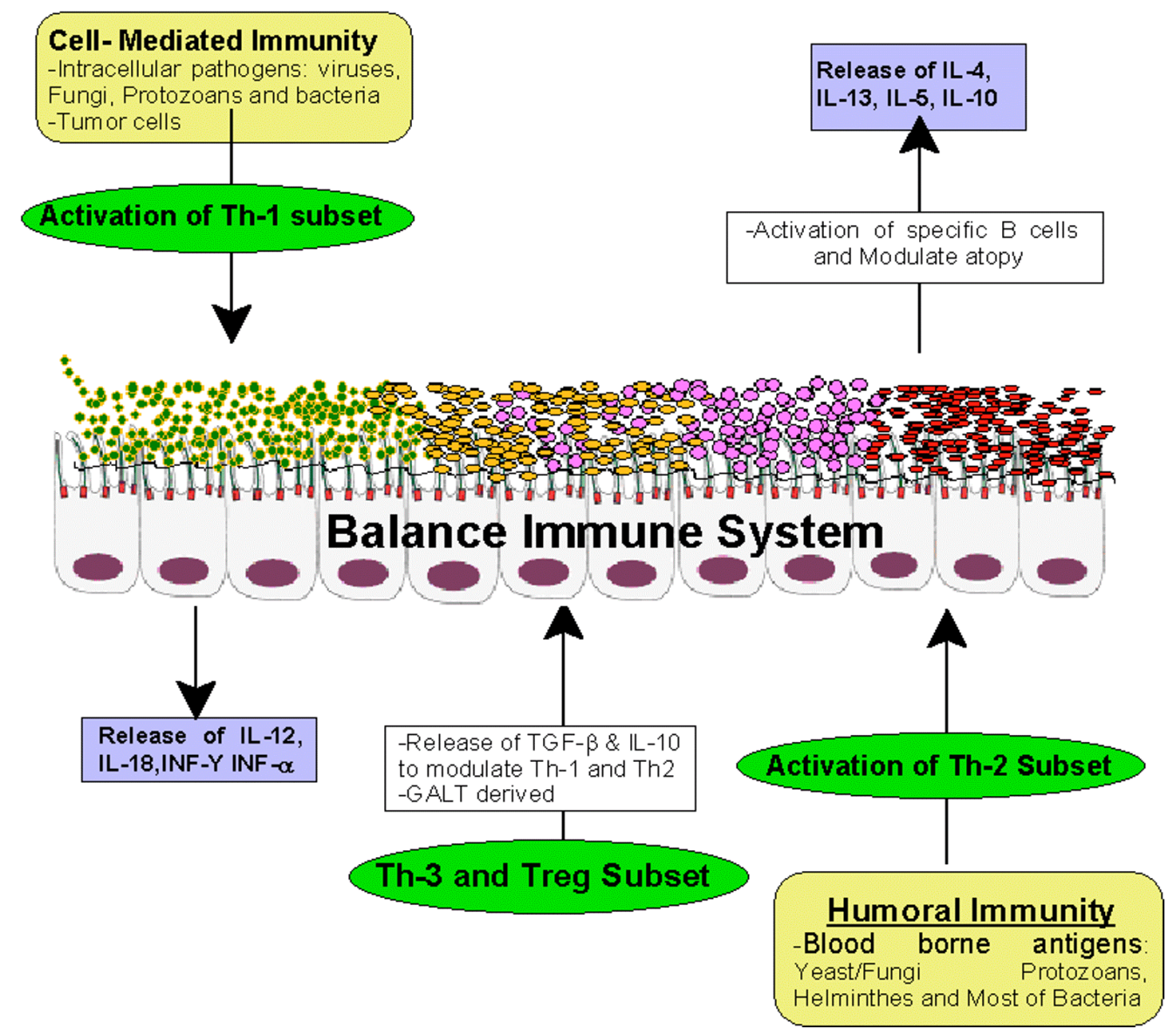

Fig. 3: This picture represents the three subsets Th1, Th2, and TH3/T (reg.) of the humoral immune system (Belkaid and Hand; 2014).

\section{Development and balancing of effectors $T$ cells immune responses}

Microbial flora also involved in balancing the effector's T-cell immune responses in the GI tract (Figure 4) (Chung et al., 2012). In germ-free mice, there is decreased number of T-helper (Th-1) and Th-17 cells since the intestinal T-cell immune response in GF animals is primarily controlled by Th-2 cells (GaboriauRouthiau et al., 2009). The imbalance T-cell immune response in GF mice can be balanced by reconstitution with conventional microbiota, indicating that the microbial flora shapes the Th-1 cell-mediated immunity (Bouskra et al., 2008). Recently this has been accepted that commensal Clostridia-related bacteria, called segmented filamentous bacteria (SFB), were involved in the induction of Th17-cell development in the small intestine (Ivanov et al., 2009; Round et al., 2010). Furthermore, SFB is not the only bacteria that can induce Th17 cells colonization of GF mice with Altered Schaedler Flora (ASF), a cocktail of 8 defined commensals, also significantly increased the numbers of Th17 cells, although the ASF is less effective than SFB (Round et al., 2010).

\section{Establishment of $\mathrm{T}$ regulatory (T-reg) cells}

Intestinal microbial floras were also essential for the establishment and function of the Foxp3+ Treg cells in the intestine (Figure 4). In condition of the imbalanced microbial flora or in GF animals the numbers of Foxp3+ Helios- Treg (iTreg) cells were significantly reduced in the colonic lamina propria (LP), but not the LP of the small intestine or mesenteric lymph nodes (Round et al., 2011; Fagarasan et al., 2010). Colonic T-reg cells can be restored with re-colonization of the microbial flora in GF animals. Bacterial species such as Clostridia, Bacteroides spp., Lactobacillus, or SFB has been reported to possess Treg inducing activity. Colonization of mice with Bacteroides fragilis, a human commensal, robustly facilitates the differentiation of Treg cells and interleukin (IL) 10 production by Treg cells, whereas 
mouse commensal strains of Bacteroides only weakly induce development of Treg cells (Round et al., 2011; Fagarasan et al., 2010).

\section{Development of B cells}

Development of B-cells occurs not only the in fetal liver and bone marrow but also occurs in the intestinal mucosa. Receptors responsible for the editing of B-cells are regulated by extracellular signals generated by the resident microbial flora (Figure 4) (Sonnenberg and Artis, 2012).

The intestinal microbial flora also involved to influence the immunoglobulin responses within the intestinal mucosa, such as IgA regulates the intestinal homeostasis. It means that commensal microbial flora participates in the development of the intestine-specific B-cell receptors representative. Most of the IgA producing mature B-cells in Peyer's of patches on the stimulation by resident microbial flora (Figure 4), the possible mechanism behind this is the participation of the microbiota in the development and organization of the GALTs. The immature formation of the germinal centers in the PPs and reduced generation of IgA-producing B-cells in the GF mice is because of the lack of the microbiota-derived signals for these events (Sonnenberg and Artis, 2012).

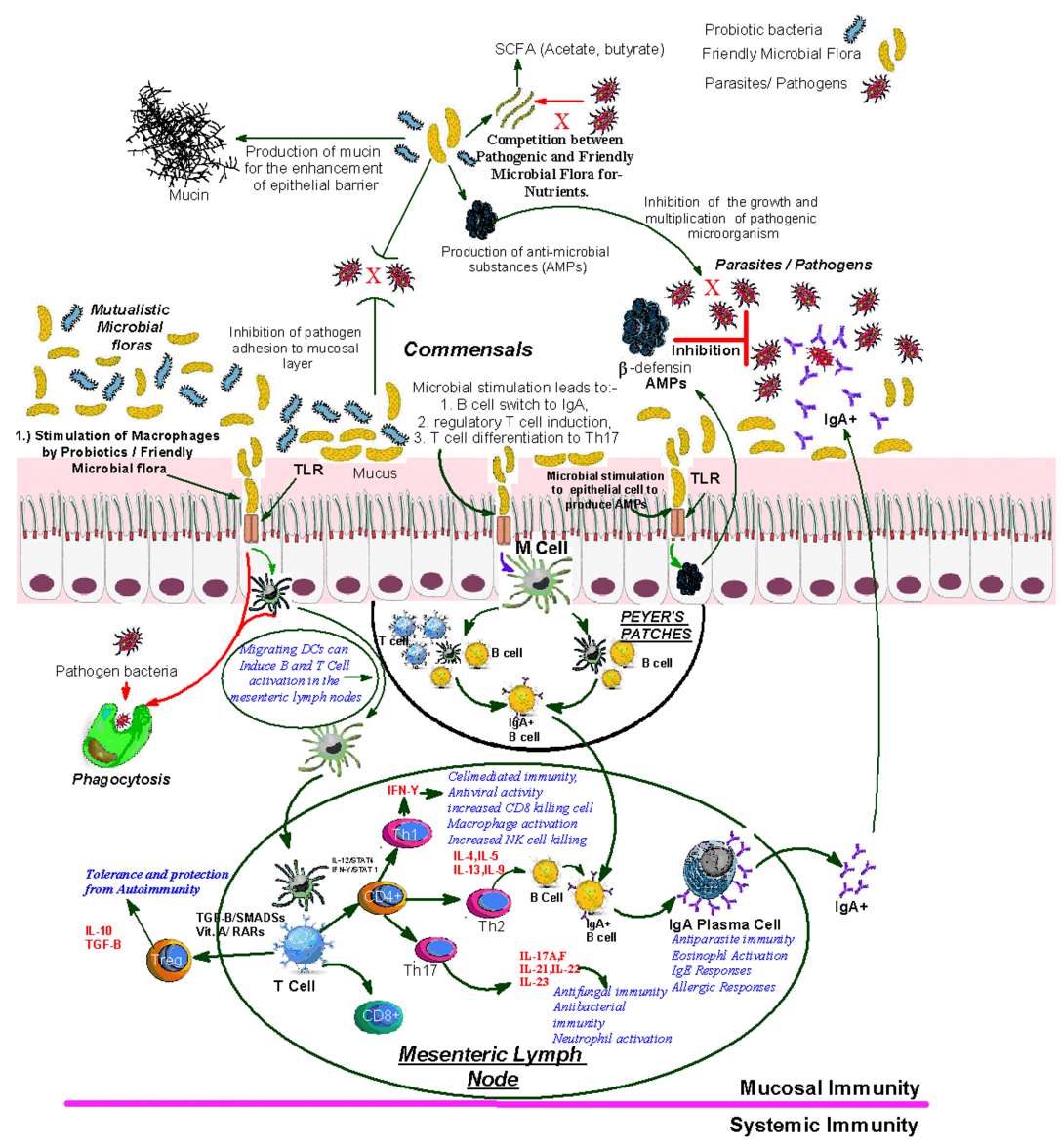

Fig. 4: Contribution of Microbial flora in the Mucosal Immune Homeostasis. T cells and CD4+ cell are a chief component of the adaptive immune system, located in the lamina propria of the intestine. On stimulation of native CD4+-T cell, they are differentiated into four major subtypes: T helper 1 (Th1), Th2, Th17, or regulatory T cell (Treg). Th1 cells are critical for the host defense against intracellular microbial infection, while Th2 cells play an important role in eliminating parasite infections. Th1 and Th17 responses have been linked to autoimmune diseases while the Th2 response has been associated with allergic reactions. Treg is a key mediator of immune tolerance; its dysfunction can lead to autoimmune disorders (Willing et al., 2011; Ohland et al., 2015).

\section{Development of Innate Lymphoid Cells (ILCs)}

The signals and metabolites produced by the microorganisms are sensed by the hematopoietic and nonhematopoietic cells of the innate immune system, which were further translated into physiological responses (Thaiss et al., 2016). The innate lymphoid cells (ILCs) are the representative of the innate immune system and they function in association with the T-cells. ILC is originated from the lymphoid precursors, grouped into (Satoh-Takayama et al., 2008): Group 1: T-bet+; Group 2: GATA-3+; and Group 3: ROR $\gamma \mathrm{t}+$.
Recently this has been evidently established that group $3(\mathrm{ROR} \gamma \mathrm{t}+)$ ILCs participating in the development of the intestinal immunity. These ILCs are similar to the Th-17 cells in the stimulation of the cytokine profile (production of IL22 and/or IL17 upon IL23 and IL1 $\beta$ stimulation) (Satoh-Takayama et al., 2008). Some Studies also reveals that commensal microbial flora is involved in the differentiation of group 3 ILCs, since the proportion of ROR $\gamma \mathrm{t}+\mathrm{NKp} 46+\mathrm{CD} 127+\mathrm{NK} 1.1-$ or $\mathrm{ROR} \gamma \mathrm{t}+\mathrm{NKp} 46+\mathrm{CD} 127+\mathrm{NK} 1.1$ into ILCs is consistently decreased in GF mice (Franchi et al., 2012; Kamada et al., 2005). 
In recent studies this has been reported that in GF mice the production of the IL22 was significantly reduced, this indicates that the function of the ILCs is regulated by commensals (Franchi et al., 2012).

\section{Development of lamina propria phagocytes}

Mononuclear phagocytes such as macrophages and dendritic cells (DCs) and polymorphonuclear phagocytes such as neutrophils are responsible for the protection of the organs and GI tract against microbial infections. The resident microbiota potentiates the production of pro-IL1 $\beta$ (the precursor of IL1 $\beta$ ) in resident macrophages. Nevertheless, full processing and secretion of pro-IL $\beta$ do not take place in phagocytes until they encounter the pathogenic microorganism. For example, Pathogens such as Salmonella and Pseudomonas aeruginosa can promptly induce secretion of the mature form of IL1 $\beta$ from intestinal macrophages, which contributes to the elimination of infectious pathogens (Kamada et al., 2005).

Unlike to microbial flora, this pathogen by injecting flagellin into the cytosol through type III secretion systems, activate the Nod-like receptor (NLR) C4 inflammation to induce caspase-1dependent processing of pro-IL1 $\beta$ (Kamada et al., 2005).

The resident microbial floras also potentiate the antiinflammatory responses of intestinal macrophages by stimulating them to produce anti-inflammatory cytokine IL10, which is needed to maintain the GI homeostasis (Rivollier et al., 2012; Zhou et al., 2007). Intestinal microbial flora also modulates the function of neutrophils, during intestinal infection with pathogen Clostrodium difficile, the commensals translocated into the intestinal tissue, where they induce expression of pro-IL1 $\beta$ in recruited neutrophils. The resident microbial flora is therefore involved in the regulation and function of intestinal phagocytes.

In response to the pathogen invasion the LP mononuclear phagocytes, including macrophages, express pro-IL1 $\beta$ for the rapid production of mature IL1 $\beta$ (Kamada et al., 2005; Rivollier et al., 2012). The building up of pro-IL1 $\beta$ in LP macrophages are required MyD88 signaling produced or induced by microbial flora (Rivollier et al., 2012). Similarly, the anti-inflammatory function of intestinal macrophages such as the impulsive production of IL-10 is also controlled by the microbial flora.

\section{ROLE OF MICROBIAL FLORA IN THE REGULATION OF IMMUNE SYSTEM}

\section{Induction and regulation of intestinal Th17 cells}

In-vitro studies reported that the differentiation of the Th-17 cell was regulated by transforming growth factor (TGF) $\beta$ and IL6 or IL21 while their expansion is mediated by IL-23 (Shaw et al., 2012; Hasegawa et al., 2010). There is reduced numbers of intestinal Th-17 cell in mice deficient with IL1 $\beta$ or the IL1 receptors. This has been reported that in GF mice the production of IL1 $\beta$ decreased in resident intestinal phagocytes. Administration of IL1 $\beta$ is sufficient to induce development of intestinal Th17 cells in GF mice. The intestinal microbiota, therefore, appears to promote the development of Th17 cells, by inducing the IL1 $\beta$ but not IL6 (Hasegawa et al., 2010).

Mice deficient in MyD88 adaptor have a low level of IL1 $\beta$ and decrease in the number of TH17 cells. MyD88 an adaptor required for the Toll-like receptor (TLR), IL1-like, and IL18 receptor signaling, involved in to increase the level of IL1 $\beta$ and development to TH17 cells in the intestine. Microbial flora might, therefore, induce IL1 $\beta$ production via TLR-MyD88 mediated signaling in the innate immune response pathway (Smith et al., 2013). Studies carried by Atarashi et al. reported that luminal ATP produced by the microbiota activate the DCs in the Lamina Propria (LP) which further promotes the development of the TH17 cell. Nevertheless, the microbial flora maintains the balance of the effectors- $T$ cell populations-mainly in concern of Th17 cells. However, more research is required to established and understand the mechanism by which microbial flora induce the Th17 cell in the intestine (Atarashi et al., 2015).

\section{Induction and regulation of Foxp3+-inducible Treg cells}

Metabolites produced by the commensals microbial flora were reported to induce the development of Treg cells. Short-chain fatty acids (SCFAs) have been proposed to regulate development and function of colonic Treg cells. Fall down in the concentration of SCFAs such as acetate, propionate, isobutyrate, and butyrate in GF mice connected with the non-functional development of intestinal Treg cells. Furthermore, again restoring of the microbial flora or supplementation with SCFAs in GF mice increase the number of Treg cell, indicating the role of the bacterial metabolite in Treg cell development. SCFAs affect Treg cell function via epigenetic regulation of the Foxp3 gene, particular butyrate, can act directly on $\mathrm{T}$ cells, increasing acetylation of the Foxp3 locus (Atarashi et al., 2015; Arpaia et al., 2013). Likewise, dietary folic acids regulate the survival of Foxp3+ Treg cells in the colon (Rossi et al., 2011). Animals having impaired or non-functioning synthetic pathways for de novo production of folic acids, then folic acids obtained from the microbial flora of intestine are likely to be involved in the induction of intestinal Treg cells (Coombes et al., 2007).

Although this has been need to establish that LP DCs may appear to be involved in the mechanism by which SCFAs, via transforming growth factor- $\beta$ (TGF- $\beta$ ), promote the development of Treg cell. CD103-expressing subsets of DCs in the LP (including $\mathrm{CD} 103+\mathrm{CD} 11 \mathrm{~b}+\mathrm{CD} 11 \mathrm{c}+$ and CD103+CD11b-CD11c+) induce differentiation of Treg cell from native CD4+ T cells via TGF $\beta$ and retinoic acid (RA) (Mazmanian et al., 2008). Treg cell induction by the microbial flora protects the mice from-colitis, infection with enteric pathogens, and allergic diarrhea. For instance, Clostridiuminduced Treg cells suppress colitis and allergic diarrhea in mice. Similarly, Treg cell induced by $B$. fragilis, reduce the intestinal inflammation caused by Helicobacter hepaticus (Suzuki et al., 2010). These studies indicate that generation, maturation, and function of Treg cell were induced by the intestinal microbial flora and their metabolite, which were further needed to maintain the GI homeostasis.

\section{Induction and regulation of IgA-producing B cells}

Commensals microbial flora regulates the development of IgA producing cell in the intestine. Commensals microbiota activates MyD88 signaling in LP DCs and follicular DCs-Cells that promotes the generation of $\operatorname{IgA}+\mathrm{B}$ cells. In response to microbial stimulation, follicular DCs in Peyer's Patches (PPs) secreteTGF $\beta$, CXCL13 and B-cell activating factor (BAFF, a member 
of the TNF family), which further stimulate the induction and IgA production (Rossi et al., 2011). Similarly, the microbial flora activates the MyD88 signaling in the subsets of LP DCs, which further leads to their expression of RA, TGF $\beta, \mathrm{TNF} \alpha$, inducible nitric oxide synthetase, BAFF, and proliferation-inducing ligands to promote the generation of $\operatorname{IgA}+\mathrm{B}$ cells (Umesaki et al., 1999). However, the microbial flora is involved in the development and maturation of intestinal B cells, but the specific bacteria have not been identified which mediate these process. Mono-colonization of GF mice with SFB, in addition to TH17 cells, can induce IgA-11 production (Umesaki et al., 1999). However, the amount of IgA in SFB mono-colonized mice is low compared to mice colonized with conventional microbiota, indicates that other bacterial species, or mixtures of commensals microbial flora, are needed for maximal induction of intestinal IgA-11.

\section{MAJOR CONSEQUENCE OF IMBALANCE OF THE MICROBIAL FLORA}

In general, the gut microbial flora and the host survive in a symbiotic manner. Dysbiosis of this balance results many diseases for example:

- $\quad$ Pseudomembranous colitis because of toxin produced by Clostridium difficile during antibiotic therapy and surgery.

- $\quad$ Sepsis because of the colonization of Escherichia coli, Enterococcus faecalis, and Enterococcus faecium, and

- Intra-abdominal abscesses due to Bacteroides fragilis (Elliott et al., 2003).

In addition, many other diseases were also resulted because of the perturbation of the microbial floral balance in GIT, includes inflammatory bowel diseases, obesity, diabetes, liver diseases, chronic heart diseases, cancers, HIV, and autism (Zhang et al., 2015). In general, the microbiota of the healthy adults was dominated with four major bacterial phylaabout $90 \%$ of the microbial flora is constituted with obligate anaerobes i.e. Firmicutes and Bacteroidetes, and to a lesser extent by Proteobacteria as well as Actinobacteria (Gevers et al., 2012). However, the composition of the gut microbiota of IBD subjects undergoes marked alterations at both taxonomical and functional level (Kostic et al., 2014; Manichanh et al., 2012). The abundance of both Bacteroidetes and Firmicutes are significantly decreased, while those of Actinobacteria and Proteobacteria are significantly increased in IBD. Concurrently, fall down in the level of the protective anaerobic microbiota generally Firmicutes (e.g. F. prausnitzii, Clostridium spp.) and Bacteroidetes (e.g. $B$. fragilis), and with an increase in colonization of facultative aerobes such as enterobacterium (Phylla: Proteobacteria), cause imbalance of the microbial flora and results in mucosal intestinal inflammation.

The structural imbalance of the microbial flora produce further consequence includes malfunctioning in function of the microbiota such as bacterial amino acid biosynthesis and carbohydrate metabolism with enhanced uptake consumption of nutrients (Morgan et al., 2012). In addition, the production of the bacterial metabolites SCFAs known for the immunosuppressive function was also suppressed (Morgan et al., 2012; Singh et al., 2014; Smith et al., 2013). In a recent study by Rooks et al., on animal model T-bet $\times$ Rag2 ulcerative colitis (TRUC) mouse for ulcerative colitis reported (Rooks et al., 2014):

- An increase in the bacterial motility.

- Tetrathionate respiration (metabolic pathway) which promote the colonization of the pathogenic Salmonella enterica subsp.

- Typhimurium in the inflamed gut (Winter et al., 2010).

- Benzoate degradation (metabolic pathway) associated with growth and virulence of Enterobacteriaceae in active colitis (Freestone et al., 2007; Lyte et al., 2011).

\section{Inflammatory bowel disease}

Inflammatory bowel disease (IBD) is characterized as ulcerative colitis (UC) and Crohn's disease (CD). This is because of the aggressive Th-1 mediated cytokine response against the luminal antigen of commensal bacteria. Besides this fault bacterial recognition by macrophages is strongly associated with the pathogenesis of IBD. Ulcerative colitis (UC) is one of the two major idiopathic IBDs. The pathogenesis of ulcerative colitis is associated with an imbalance in the composition of the microbial flora i.e. there is decreased in the number of beneficial bacteria such as lactobacilli and bifidobacteria with increased in the colonization of pro-inflammatory bacteria such as Enterobacteriaceae, and Bacteroides fragilis (Mishra et al., 2012).

In an investigation by Macpherson AJ on animal colitis model, they reported that $E$. coli may be served as a biomarker for the severity of the colitis. They found that pathogenesis of colitis is associated with higher $E$. coli colonization and with a high load of bacterial TLR2 ligands. Bacterial TLR2 ligands and their products intensify the acute inflammation via TLR2 and TLR-4 signaling and potentially trigger the TLR-dependent accumulation of neutrophils and T cells (Macpherson et al., 2007; Kwon et al., 2010).

\section{Crohn's disease (CD)}

Another type of IBD is Crohn's disease (CD). This has been accepted that Crohn's disease is an autoimmune disorder, involves the activation of the immune system against the normal flora of GIT and causes inflammation of Mucosa (Bhattacharjee, 2012). Seksik et al. found a significant increase in the enterobacteria in fecal microflora of both active and inactive Crohn's disease patients than the healthy individuals (Seksik et al., 2003). In one more study, this has been reported in Crohn's disease patients that there is a decrease in the number of Dialister invisus, Clostridium cluster XIVa (an uncharacterized species), Faecalibacterium prausnitzii and Bifidobacterium adolescentis with an increase in the colonization of Ruminococcus gnavus (Joossens et al., 2011).

Commensal E. coli strain in Crohn's disease induce the release of tumor necrosis factor- $\alpha$ (TNF- $\alpha$ ) and interleukin-8 (IL-8) from the inflamed mucosa. On the other hand, some strains of lactobacilli such as $L$. casei suppress the inflammatory responses and also downregulate the spontaneous release of TNF- $\alpha$ induced by E. coli (Tighe et al., 2011). Therefore, the approach of the treatment of the CD may be based to eliminate some bacteria with antibiotics or to balance the gut flora with more beneficial bacteria, by the use of probiotics and probiotics (Fujimori et al., 2007). Proposed approaches to manage the CD include: 
- by improving the short chain fatty acids (SCFA) production patterns (Rooks et al., 2016),

- $\quad$ improving Th1/Th2 ratios, by decreasing the proinflammatory cytokine secretion,

- $\quad$ inhibiting the colonization of pathogens, and

- $\quad$ improving and enhancing mucosal barrier function.

In 1917 , this has been accepted that $E$. coli Nissle is a nonpathogenic strain of $E$. coli, which suppresses the growth of enteropathogenic bacteria. It was proposed that E. coli Nissle, by inhibiting the colonization of enteropathogenic bacteria, may produce a long-term suppression of remission of $\mathrm{CD}$. In an investigation by Malchow, on 28 patients suffering from active $\mathrm{CD}$, were treated with a tapering dose of prednisolone and either placebo or E. coli Nissle. The E. coli Nissle was given for 24 days in an increasing dose to the last dose of $5 \times 10^{10}$ bacteria per day. They assessed for the remission and reported that the patients in the placebo group have higher relapse rate about $63.6 \%$ as compared to the E. coli group which is $33.3 \%$ (Malchow, 1997).

\section{Consequences of obesity}

Commensal microbial flora plays an important role in controlling the diet-induced obesity (Karimi et al., 2015). This has been reported that Germ-free mice found to be thinner with a less adipose tissue even when subjected to a high-fat diet (Ding et al., 2010). The high-fat diet promotes composition of microbial flora with a higher level of luminal Firmicutes and Proteobacteria and lower levels of Bacteroidetes (Hildebrandt et al., 2009). This reveals that obesity may be associated with the ecological composition of the gut microbial flora. SCFAs such as Butyrate and propionate were reported to lower the incidence of the dietinduced obesity by activating the complementary mechanism for intestinal gluconeogenesis (IGN). Butyrate directly activated Intestinal gluconeogenesis gene expression via an increase the level of cAMP in enterocytes, while propionate acts as free fatty acid receptor-3 (FFAR-3) agonist and promotes the glucose metabolism (Morgen et al., 2014). Conjugated linoleic acid (CLA) has also been reported for its anti-obesity effects. There were six strains of bacteria (four Bifidobacterium breve strains, a Bifidobacterium bifidum strain and a Bifidobacterium pseudolongum strain) from the GIT microbial flora have been reported for their capability to produce different CLA and conjugated $\alpha$-linolenic acid isomers from free linoleic acid and $\alpha$-linolenic acid available from diets, such as food products from natural, and processed cheeses, beef, milk fat, yogurt, and plant oil (Gorissen et al., 2010). Dietary probiotic and probiotics preparations, namely synbiotics, can also be used to control the obesity (Mozaffarian et al., 2011; Solis et al., 2010). Several studies reveal that eating yogurt amazingly prevents age-associated weight gain (Safavi et al., 2013).

\section{Consequences of cancers}

The pathogenesis of colon cancer generally associated with the imbalance of the intestinal bacterial community or infestation pathogens. Gut bacteria by triggering macrophages produce diffusible clastogens or chromosome-breaking factors which may further mediate as DNA damage and chromosomal instability in neighboring cells (Zhang et al., 2015). Intestinal preoxidative stress may also contribute bacteria-associated intestinal cancers (Chu et al., 2003).

Butyric acid is a vital nutrient for the colon cells since it reduces the incidence of proliferation and induction of apoptosis of human colon cancer cells. The level of butyric acid was significant decreases in the stool samples of colon cancer patients compared to healthy subjects since there is a decrease in the colonization of butyrate-producing bacteria such as Ruminococcus spp. and Pseudobutyrivibrio ruminis (Zhang et al., 2015).

In an investigation this has been reported that cyclophosphamide distorted the balance of microbial flora in the small intestine of mouse models and it also promotes the translocation of some selected species of Gram-positive bacteria in the secondary lymphoid organs, which further stimulate the generation of a specific subset of "pathogenic-T-helper-17" (pTh17) cells and memory Th1 immune responses (94). Germfree mice treated with antibiotics or bearing tumor, inhibit the colonization of the gram-positive bacteria which results in a fall in the pTh17 responses and their tumors were also resistant to cyclophosphamide. The results indicate that the gut flora may involve in the shape and regulation of the anticancer immune response (Viaud et al., 2013). Dietary supplementation of Bifidobacterium longum significantly suppresses the incidence of the colon tumor, multiplicity, and volume of the tumor (Singh et al., 1997). Bifidobacterium longum exhibit the inhibition of the azoxymethane-induced cell proliferation, ornithine decarboxylase activity and expression of ras-p21 oncoprotein activity significantly (Safavi et al., 2013).

\section{CONCEPT OF "PROBIOTIC" (Live-Microorganism Pharmaceutical Preparations)}

Probiotic is the preparation containing beneficial and nonpathogenic bacteria meant for the oral administration along with dietary supplements to improve and restore the microbial flora of gastrointestinal tract (Johnston et al., 2012). Probiotics are defined by the World Health Organization as "live microorganisms that can provide benefits to human health when administered in adequate amounts, which confer a beneficial health effect on the host" (WHO/2001). Probiotic are often found as a better approach and effective preparations in the treatment of wide range of disease associated imbalance of the microbiota of gastrointestinal tract such as C. difficile infection, antibiotic-associated diarrhea, and acute infectious diarrhea (Johnston et al., 2012; Videlock et al., 2012). Probiotics establish the microbial balance through various mechanisms including preventing the colonization of pathogenic organism by means of their ability to compete for nutrients or producing antimicrobial proteins, modifying the immune responses, improving the mucosal barrier functions, lowering the $\mathrm{pH}$ of GIT and also by detoxifying the ingested carcinogens (Johnston et al., 2012). Nowadays, microbial genera of Lactobacillus and Bifidobacterium are considered as safest for the probiotic preparations.

- Lactobacillus genera: acidophilus, brevis, casei, fermentum, gasseri, johnsonii, paracasei, plantarum, delbrueckii, rhamnosus, reuteri and salivarius.

- Bifidobacterium genera: adolescentis, animalis, bifidum, breve, and longum (Hill et al., 2014).

In addition, microbial strains belonging to 
Propionibacterium and Streptococcus (particularly thermophilus) were also considered for the probiotics preparations. This has been reported that dairy propionibacterium are able to restore the gut microbial balance, inhibit the colonization of the pathogenic microbes and also participate in the immunomodulatory activity (Zarate et al., 2012), while S. thermophilus is able to produce excess of the enzyme lactase, hence, effective in the prevention of lactose intolerance (Rul et al., 2012).

The world's most documented and recommended probiotics preparation includes, strains Lactobacillus rhamnosus GG $\left(\right.$ Valio $\left.^{\circledR}\right)$, Lactobacillus paracasei Shirota $\left(\right.$ Yakult $\left.^{\mathbb{}}\right)$ and Bifidobacterium lactis BB12 (Chr. Hansen $\left.{ }^{\circledR}\right)$, are reported effective in the treatment of infections including Clostridium difficile infection, protection against Helicobacter pylori infection, rotaviral diarrhea, antibiotic-associated diarrhea, Travelers' diarrhea, as well as some other bacterial diarrheas. They are also prescribed by the doctors in metabolic imbalance such as lactose intolerance and in immune response modulation (Hui, 2006). The major physiological mechanisms of probiotic strains are based on their ability to (Otles, 2013) produce of inhibitory substances i.e., hydrogen peroxide or bacteriocins to inhibit the colonization grampositive and gram-negative bacteria, compete with pathogenic microbes for their nutrients, attachment on the intestinal epithelial surface and by blocking attachment sites, as well as by modulating and activating the immunity system against pathogens.

\section{Probiotic: An approach to restore the microbial flora}

Probiotic preparations influence the several pathways of immune responses including humoral, cellular and innate immunity. Recently, this has been accepted that probiotics preparations can influence the secretion of cytokines and also involved to direct native helper $\mathrm{T}$ cells for Th1 mediated Cellular immunity or Th2 mediated humoral immune responses.

\section{Th1 cell-mediated immune response}

Th1 pathway induces the cell-mediated immunity and prevents the infections associated with intracellular pathogens such as viruses, certain bacteria, yeast, fungi, and protozoans. Th1 cellmediated immunity also plays an important role in preventing the incidence and development of the tumor. Continuous stimulation of the native $\mathrm{T}$ cell for $\mathrm{Th} 1$ cell pathway produces a large amount of pro-inflammatory cytokines including IFN- $\gamma$ and TNF- $\alpha$. These cytokines further activate macrophages to produce additional proinflammatory mediators i.e. IL-12 and IL-18. A persistent Th1 cell-mediated inflammatory episode of the gastrointestinal tract is the main etiology behind the several pathological conditions such as Crohn's disease, H. pylori gastritis, cellular autoimmunity, chronic recurrent inflammation and possibly rheumatoid arthritis, multiple sclerosis and systemic lupus erythematosus (Leah et al., 2009). Certain probiotic strains help to down-regulate over activation Th1 cell-mediated immunity responses and restore the balance between Th1 and Th2 mediated immune responses.

Overproduction of the TNF- $\alpha$ via Th1 cell-mediated immunity plays a key factor to induce the inflammation of gastrointestinal tract in the pathogenesis of the Cohn's disease involved in the In an investigation by Borruel et al. studied the effect of probiotic bacteria on the TNF- $\alpha$ production in the ileal specimens of 10 patients suffering from Crohn' disease. They found a significant fall in the production to TNF- $\alpha$ by the inflamed mucosa when cultured with $L$. casei or $L$. bulgaricus, but not with $L$. crispatus or E. coli (Borruel et al., 2002). They reported that probiotic strains have an ability to interact with the immune-competent cell and inhibit the release of the pro-inflammatory cytokines.

\section{Th2 cell-mediated immune response}

Th2 cell pathway regulates the humoral immunity responses. It acts by inducing the release of cytokines IL-4, IL-13, IL-5 and IL-10 that activate the formation and release of specific B cells, mast cell and/or eosinophils (Kidd, 2003). Persistent activation of Th2 cell pathway leads atopy, ulcerative colitis, and eosinophilic rhinosinusitis. This has been accepted that Extracellular proteins secreted by probiotic bacterial strains can able to diffuse into the mucus layer and interact with the epithelial and immune cells. The interaction of extracellular proteins with the epithelial and immune cells generate signals which were further communicated to the nucleus of these cells via several cascades of biochemical pathway including mitogen-activated protein kinases (MAPKs), phosphatidylinositol 3-kinase (PI-3K) and glycogen synthase kinase-3 (GSK-3) (Hoarau et al., 2006).

Activation of these biochemical cascades initiate signaling pathways and cellular responses such as secretion of chemokines, cytokines, antibacterial proteins (AMP), secretion of mucus and also induces changes in the surface properties of mucosal barrier including rearrangement of tight junctions and modulation in the immune responses of gut-associated lymphoid tissue (GALT) cells (102). For example, 'Serpin' extracellular proteins secreted by the probiotic bacterial strain of Bifidobacteria species (Bifidobacterium breve, Bifidobacterium dentium, and $B$. longum subsp. infantis) improve and enhances the mucosal barrier functions and also able to modulate the GALT immune function, in animals and cellular models. In a recent study, this has been found that $B$. longum subsp. Infantis secrets uncharacterized extracellular proteins which improve and enhances the mucosal barrier functions by increasing the production of zonula occludens- 1 and occludin, the two tight-junction proteins (TJPs) in epithelial cells (Ewaschuk et al., 2008). A Probiotic strain lactobacilli acidophilus NCFM cell secretes S-layer protein A (SlpA) which induces the production of IL-10 in the dendritic cells by doing so it produces anti-inflammatory responses (Konstantinov et al., 2008).

\section{Conclusions and prospects}

The main focus of this review is to understand and explore the role of microbial flora in the regulation of the host immune system. Microbial flora also actively involved in the metabolic process of the host, synthesis of vitamins, production of nutrients, enhancement of mucosal barrier functions, guts protection and also inhibits the colonization of pathogenic microorganism. There is a symbiotic relationship between the need of both host and microbial flora, and even between the different strains of the microbial flora in respect of their nutrients or removal of their waste material. Furthermore, more studies were needed to investigate symbiotic relationship and functional aspects of millions of bacterial strain available in our gastrointestinal tract.

This has been accepted that alteration in the composition of gut microbiota perturbs the microbial ecology which may result in many diseases such as obesity, systemic infections, 
IBD, autoimmune disorders, and even colon cancers. Nowadays, probiotics and prebiotics have been widely clinically practiced to restore the imbalanced microbial flora as an alternate strategy of treatment, but still, more studies and clinical trials were required to explore the exact basis of pathogenesis and how and which microbial flora strain can be a remedy for diseases, associated with the microbial flora of GIT.

\section{FINANCIAL SUPPORT AND SPONSORSHIP}

Nil.

\section{CONFLICT OF INTERESTS}

There are no conflicts of interest.

\section{REFERENCES}

Alakomi HL, Skytta E, Saarela M, Mattila-Sandholm T, LatvaKala K, Helander IM. Lactic acid permeabilizes gram-negative bacteria by disrupting the outer membrane. Appl Environ Microbiol, 2000; 66:2001-2005.

Vieira AT, Teixeira MM, Martins FS. The role of probiotics and prebiotics in inducing gut Immunity. Frontiers in immunology-Mucosal Immunity, 2013; 4(445):1-12.

Arpaia N, Campbell C, Fan X, Dikiy S, van der Veeken J, Deroos P, Liu H, Cross JR, Pfeffer K, Coffer PJ, Rudensky AY. Metabolites produced by commensal bacteria promote peripheral regulatory T-cell generation. Nature, 2013; 19, 504(7480):451-5.

Atarashi K, Tanoue T, Ando M, Kamada N, Nagano Y, Narushima S, Suda W, Imaoka A, Setoyama H, Nagamori T, Ishikawa E, Shima T, Hara T, Kado S, Jinnohara T, Ohno H, Kondo T, Toyooka K, Watanabe E, Yokoyama S, Tokoro S, Mori H, Noguchi Y, Morita H, Ivanov II, Sugiyama T, Nunez G, Camp JG, Hattori M, Umesaki Y, Honda K. Th17 Cell Induction by Adhesion of Microbes to Intestinal Epithelial Cells. Cell. 2015; 163(2):367-80.

Baddini Feitoza A, Fernandes Pereira A, Ferreira da Costa N, Gonçalves Ribeiro B. Conjugated linoleic acid (CLA): effect modulation of body composition and lipid profile. Nutr Hosp, 2009; 24(4):422-8.

Bhattacharjee A. Oral micro-particulate colon targeted drug delivery system for the treatment of Crohn's disease: A review. Int J Life Sci Pharm Res, 2012; 1:31-39.

Bourlioux P, Koletzko B, Guarner F, Braesco V. The intestine and its microflora are partners for the protection of the host: report on the Danone Symposium "The intelligent intestine," held in Paris, June 14, 2002. Am J Clin Nutr, 2003; 78:675-83.

Bourriaud C, Akoka S, Goupry S, Robins R, Cherbut C, Michel C. Butyrate production from lactate by human colonic microflora. Reprod Nutr Dev, 2002; 42:S55.

Bouskra D, Brezillon C, Berard M, Werts C, Varona R, Boneca IG, Eberl G. Lymphoid tissue genesis induced by commensals through NOD1 regulates intestinal homeostasis. Nature, 2008; 456:507-10.

Carvalho FA, Aitken JD, Vijay Kumar M, Gewirtz AT. Toll-like receptor-gut microbiota interactions: perturb at your own risk. Annu Rev Physiol, 2012; 74:177-98.

Cash HL, Whitham CV, Behrendt CL, Hooper LV. Symbiotic bacteria direct expression of an intestinal bactericidal lectin. Science, 2006; 313:1126-1130

Ohland CL, Jobin C. Microbial Activities and Intestinal Homeostasis: A Delicate Balance Between Health and Disease. Cellular and Molecular Gastroenterology and Hepatology, 2015; (1):28-39.

Chung H, Pamp SJ, Hill JA, Surana NK, Edelman SM, Troy EB, Reading NC, Villablanca EJ, Wang S, Mora JR, Umesaki Y, Mathis D, Benoist C, Relman DA, Kasper DL. Gut immune maturation depends on colonization with a host-specific microbiota. Cell, 2012; 149:1578-93.

Clayton TA, Baker D, Lindon JC, Everett JR, Nicholson JK. Pharmacometabonomic identification of a significant host microbiometabolic interaction affecting human drug metabolism. Proc Natl Acad Sci USA, 2009; 106:14728-14733.
Coombes JL, Siddiqui KR, Arancibia-Carcamo CV, Hall J, Sun $\mathrm{CM}$, Belkaid Y, Powrie F. A functionally specialized population of mucosal CD103+ DCs induces Foxp3+ regulatory T cellsvia a TGF-beta and retinoic acid-dependent mechanism. J Exp Med, 2007; 204:1757-64.

Devillard E, McIntosh FM, Duncan SH, Wallace RJ. Metabolism of linoleic acid by human gut bacteria: different routes for biosynthesis of conjugated linoleic acid. J Bacteriol, 2007; 189:2566-2570.

Devillard E, McIntosh FM, Paillard D, Thomas NA, Shingfield KJ, Wallace RJ. Differences between human subjects in the composition of the faecal bacterial community and faecal metabolism of linoleic acid. Microbiology, 2009; 155:513-520

Di Giacinto C, Marinaro M, Sanchez M, Strober W, Boirivant M. Probiotics ameliorate recurrent Th1-mediated murine colitis by inducing IL-10 and IL-10-dependent TGF-beta bearing regulatory cells. J Immunol, $2005 ; 174: 3237-46$

Gevers D, Palaniappan K, Weinstock G. 2012. Human Microbiome Project Consortium. Structure, function and diversity of the healthy human microbiome. In: Nature, 486, Macmillan Publishers Limited 207-214.

Elliott PJ, Zollner TM, Boehncke WH. Proteasome inhibition: a new anti-inflammatory strategy. J Mol Med, 2003; 81:235-245.

Erickson KL, Hubbard NE. Probiotic immunomodulation in health and disease. J Nutr, 2000; 130(Suppl 2):S403-9.

Isolauri E, Sütas Y, Kankaanpää P, Arvilommi H, Salminen S, Probiotics: effects on immunity, Am J Clin Nutr, 2001; 73(suppl):444S-50S

Fagarasan S, Kawamoto S, Kanagawa O, Suzuki K. Adaptive immune regulation in the gut: $\mathrm{T}$ cell dependent and $\mathrm{T}$ cell-independent IgA synthesis. Annu Rev Immunol, 2010; 28:243-73.

Franchi L, Kamada N, Nakamura Y, Burberry A, Kuffa P, Suzuki S, Shaw MH, Kim YG, Nunez G. NLRC4-driven production of IL-1beta discriminates between pathogenic and commensal bacteria and promotes host intestinal defense. Nat Immunol, 2012; 13:449-56.

Freestone PP, Walton NJ, Haigh RD, Lyte M. Influence of dietary catechols on the growth of enteropathogenic bacteria. Int J Food Microbiol, 2007; 119:159-169.

Fujimori S, Tatsuguchi A, Gudis K, et al. High dose probiotic and prebiotic cotherapy for remission induction of active Crohn's disease. J Gastroenterol Hepatol, 2007; 22(8):1199-204.

Karimi G, Sabran MR, Jamaluddin R, Parvaneh K, Mohtarrudin $\mathrm{N}$, Ahmad Z. The anti-obesity effects of Lactobacillus casei strain Shirota versus Orlistat on high fat diet-induced obese rats. Food Nutr Res, 2015; 59:1-9.

Gaboriau-Routhiau V, Rakotobe S, Lecuyer E, Mulder I, Lan A, Bridonneau C, Rochet V, Pisi A, De Paepe M, Brandi G, Eberl G, Snel J, Kelly D, Cerf-Bensussan N. The key role of segmented filamentous bacteria in the coordinated maturation of gut helper $\mathrm{T}$ cell responses. Immunity, $2009 ; 31: 677-89$

Gordon HA, Bruckner-Kardoss E, Wostmann BS. Aging in germ-free mice: life tables and lesions observed at natural death. J Gerontol, $1966 ; 21: 380-7$

Guarner F, Malagelada JR, Gut flora in health and disease. Lancet, 2003; 361:512-9.

Hasegawa M, Osaka T, Tawaratsumida K, Yamazaki T, Tada H, Chen GY, Tsuneda S, Nunez G, Inohara N. Transitions in oral and intestinal microflora composition and innate immune receptor dependent stimulation during mouse development. Infect Immun, 2010; 78:639-50.

Hill C, Guarner F, Reid G, Gibson GR, Merenstein DJ, Pot B, Morelli L, Canani RB, Flint HJ, Salminen S, et al. Expert consensus document. The International Scientific Association for Probiotics and Prebiotics consensus statement on the scope and appropriate use of the term probiotic. Nat Rev Gastroenterol Hepatol, 2014; 11(8):506-514.

Hooper LV, Stappenbeck TS, Hong CV, Gordon JI. Angiogenins: a new class of microbicidal proteins involved in innate immunity. Nat Immunol, 2003; 4:269-273.

Hooper LV. Do symbiotic bacteria subvert host immunity? Nat Rev Microbiol, 2009; 7:367-374. 
Hui YH. 2006. Handbook of food science, technology, and engineering. In: Hi YH, ed. Taylor and Francis. CRC Press, volume 4.

Ivanov, Atarashi K, Manel N, Brodie EL, Shima T, Karaoz U, Wei D, Goldfarb KC, Santee CA, Lynch SV, Tanoue T, Imaoka A, Itoh K, Takeda K, Umesaki Y, Honda K, Littman DR. Induction of intestinal Th17 cells by segmented filamentous bacteria. Cell, 2009; 139:485-98.

Joossens M, Huys G, Cnockaert M, de Preter V, Verbeke K, Rutgeerts P, Vandamme P, Vermeire S. Dysbiosis of the faecal microbiota in patients with Crohn's disease and their unaffected relatives. Gut, 2011; 60, 631-637.

Rodríguez JM, Murphy K, Carmen M. The composition of the gut microbiota throughout life, with an emphasis on early life. Microbial Ecology in Health \& Disease, 2015; 26:26050

Kamada N, Hisamatsu T, Okamoto S, Sato T, Matsuoka K, Arai K, Nakai T, Hasegawa A, Inoue N, Watanabe N, Akagawa KS, Hibi T. Abnormally differentiated subsets of intestinal macrophage play a key role in Th1-dominant chronic colitis through excess production of IL-12 and IL23 in response to bacteria. J Immunol, 2005; 175:6900-8.

Kamada N, Nunez G. Role of the gut microbiota in the development and function of lymphoid cells. J Immunol, 2013; 190:138995.

Todar K. The Normal Bacterial Flora of Humans. Web Review of Todar's (online) Textbook of Bacteriology, The Good, the Bad, and the Deadly, page 4, http://www.textbookofbacteriology.net (Accessed, 2012).

Kim YS, Ho SB. Intestinal goblet cells and mucins in health and disease: recent insights and progress. Curr Gastroenterol Rep, 2010; 12:319-330.

Kostic AD, Xavier RJ, Gevers D. The microbiome in inflammatory bowel disease: currentstatus and the future ahead. Gastroenterology, 2014; 146:1489-1499.

Kwon HK, Lee CG, So JS, et al. Generation of regulatory dendritic cells and $\mathrm{CD} 4+\mathrm{Foxp} 3+\mathrm{T}$ cells by probiotics administration suppresses immune disorders. Proc Natl Acad Sci USA, 2010; 107:21592164.

Leah G, Gillingham MS, Lescheid DW. Probiotics and Mucosal Immunity: Strain-specific effects on Th1/Th2 cell modulation. Int J N M, 2009; 4(1):18-22

López-Boado YS, Wilson CL, Hooper LV, Gordon JI, Hultgren SJ, Parks WC. Bacterial exposure induces and activates matrilysin in mucosal epithelial cells. J Cell Biol, 2000; 148:1305-1315.

Lyte M, Vulchanova L, Brown DR. Stress at the intestinal surface: catecholamines and mucosa bacteria interactions. Cell Tissue Res, $2011 ; 343: 23-32$

Macfarlane S, Macfarlane GT. Regulation of short-chain fatty acid production. Proc Nutr Soc, 2003; 62:67-72.

Macpherson AJ, Slack E. The functional interactions of commensal bacteria with intestinal secretory IgA. Curr Opin Gastroenterol, 2007; 23:673-678.

Magwira CA, Kullin B, Lewandowski S, Rodgers A, Reid SJ, Abratt VR. Diversity of faecal oxalate-degrading bacteria in black and white South African study groups: insights into understanding the rarity of urolithiasis in the black group. J Appl Microbiol, 2012; 113:418-428.

Malchow HA. Crohn's disease and Escherichia coli. A new approach in therapy to maintain remission of colonic Crohn's disease. J Clin Gastroenterol, 1997 Dec; 25(4):653-8.

Manichanh C, Borruel N, Casellas F, Guarner F. The gut microbiota in IBD. Nat Rev Gastroenterol Hepatol, 2012; 9:599-608.

Mazmanian SK, Liu CH, Tzianabos AO, Kasper DL. An immunomodulatory molecule of symbiotic bacteria directs maturation of the host immune system. Cell, 2005; 122:107-18.

Mazmanian SK, Round JL, Kasper DL. A microbial symbiosis factor prevents intestinal inflammatory disease. Nature, 2008; 453:620-5.

Wilson M. 2004. Microbial Inhabitants of Humans: Their Ecology and Role in Health and Disease. Cambridge University Press; ISBN-10:0521841585.

Rooks MG, Garrett WS. Gut microbiota, metabolites and host immunity. Nat Rev Immunol, 2016 May 27; 16(6):341-352.

Morgan XC, Tickle TL, Sokol H, Gevers D, Devaney KL, Ward DV, Reyes JA, Shah SA, LeLeiko N, Snapper SB, et al. Dysfunction of the intestinal microbiome in inflammatory bowel disease and treatment. Genome Biol, 2012; 13:R79.

Neurath MF, Finotto S, Glimcher LH. The role of Th1/Th2 polarization in mucosal immunity. Nat Med, 2002; 8:567-73.

Otles S. 2013. Probiotics and prebiotics in food, nutrition and health. CRC Press.

Rakoff-Nahoum S, Paglino J, Eslami-Varzaneh F, Edberg S, Medzhitov R. Recognition of commensal microflora by toll-like receptors is required for intestinal homeostasis. Cell, 2004; 118:229-41.

Martín R, Miquel S, Ulmer J, Kechaou N, Langella P, BermúdezHumarán LG. Role of commensal and probiotic bacteria in human health: a focus on inflammatory bowel disease. Microbial Cell Factories, 2013; $12: 71$.

Rivollier A, He J, Kole A, Valatas V, Kelsall BL. Inflammation switches the differentiation program of Ly6Chi monocytes from antiinflammatory macrophages to inflammatory dendritic cells in the colon. $\mathrm{J}$ Exp Med, 2012; 209:139-55.

Rooks MG, Veiga P, Wardwell-Scott LH, Tickle T, Segata N, Michaud M, Gallini CA, Beal C, Van Hylckama-Vlieg JE, Ballal SA, et al. Gut microbiome composition and function in experimental colitis during active disease and treatment-induced remission. ISME J, 2014; 8:14031417.

Rossi M, Amaretti A, Raimondi S. Folate production by probiotic bacteria. Nutrients, 2011; 3:118-34.

Round JL, Lee SM, Li J, Tran G, Jabri B, Chatila TA, Mazmanian SK. The Toll-like receptor 2 pathway establishes colonization by a commensal of the human microbiota. Science, 2011; 332:974-7.

Round JL, Mazmanian SK. Inducible Foxp3+ regulatory T-cell development by a commensal bacterium of the intestinal microbiota. Proc Natl Acad Sci USA, 2010; 107:12204-9.

Rul F, Ben-Yahia L, Chegdani F, Wrzosek L, Thomas S, Noordine ML, Gitton C, Cherbuy C, Langella P, Thomas M. Impact of the metabolic activity of Streptococcus thermophilus on the colon epithelium of genotobiotic rats. J Biol Chem, 2011; 286(12):10288-96.

Jandhyala SM, Talukdar R, Subramanyam C, Vuyyuru H, Sasikala M, Reddy DN. Role of the normal gut microbiota. World J Gastroenterol, 2015; 21(29):8787-8803.

Salzman NH, Underwood MA, Bevins CL. Paneth cells, defensins, and the commensal microbiota: a hypothesis on intimate interplay at the intestinal mucosa. Semin Immunol, 2007; 19:70-83.

Satoh-Takayama N, Vosshenrich CA, Lesjean-Pottier S, Sawa S, Lochner M, Rattis F, Mention JJ, Thiam K, Cerf-Bensussan N, Mandelboim O, Eberl G, Di Santo JP. Microbial flora drives interleukin 22 productions in intestinal NKp46+ cells that provide innate mucosal immune defense. Immunity, 2008; 29:958-70.

Seksik P, Rigottier-Gois L, Gramet G, Sutren M, Pochart P, Marteau P, Jian R, Dore J. Alterations of the dominant faecal bacterial groups in patients with Crohn's disease of the colon. Gut, 2003; 52:237242.

Shanahan F. The host-microbe interface within the gut. Best Pract Res Clin Gastroenterol, 2002; 16(6):915-931.

Shaw MH, Kamada N, Kim YG, Nunez G. Microbiota-induced IL-1beta, but not IL-6, is critical for the development of steady-state TH17 cells in the intestine. J Exp Med, 2012; 209:251-8.

Sidhu H, Hoppe B, Hesse A, Tenbrock K, Brömme S, Rietschel E, Peck AB. Absence of Oxalobacter formigenes in cystic fibrosis patients: a risk factor for hyperoxaluria. Lancet, 1998; 352:1026-1029.

Singh N, Gurav A, Sivaprakasam S, Brady E, Padia R, Shi H, Thangaraju M, Prasad PD, Manicassamy S, Munn DH, et al. Activation of Gpr109a, receptor for niacin and the commensal metabolite butyrate, suppresses colonic inflammation and carcinogenesis. Immunity, 2014; 40:128-139.

Smith K, McCoy KD, Macpherson AJ. Use of axenic animals 
in studying the adaptation of mammals to their commensal intestinal microbiota. Semin Immunol, 2007; 19:59-69.

Smith PM, Howitt MR, Panikov N, Michaud M, Gallini CA, Bohlooly YM, Glickman JN, Garrett WS. The microbial metabolites, shortchain fatty acids, regulate colonic Treg cell homeostasis. Science, 2013; 341:569-73.

Sonnenberg GF, Artis D. Innate lymphoid cell interactions with microbiota: implications for intestinal health and disease. Immunity, 2012; 37:601-10.

Sujatha S, Narayan, Jalgaonkar S, Shahani S, Kulkarni VN Probiotics: current trends in the treatment of diarrhea. Hong Kong Med J, $2010 ; 16: 213-8$

Mishra SK, Mishra P, Saxena M, Probiotics: An Approach for Better Treatment. RJPBCS, 2012; 3(2):1042-1061.

Suzuki K, Maruya M, Kawamoto S, Sitnik K, Kitamura H, Agace WW, Fagarasan S. The sensing of environmental stimuli by follicular dendritic cells promotes immunoglobulin A generation in the gut. Immunity, 2010; 33:71-83.

Takeuchi O, Akira S. Pattern recognition receptors and inflammation, Cell. 2010; 140:805-820.

Thaiss CA, Zmora N, Levy M, Elinav E. The microbiome and innate immunity. Nature, 2016; 535(7610):65-74

Tighe MP, Cummings J, Afzal NA. Nutrition and inflammatory bowel disease: Primary oradjuvant therapy. Curr Opin Clin Nutr Metab Care, 2011; 14:491-496.

Umesaki Y, Setoyama H, Matsumoto S, Imaoka A, Itoh K. Differential roles of segmented filamentous bacteria and clostridia in development of the intestinal immune system. Infect Immun, 1999; 67:3504-11

Vasiljevic T, Shah NP. Probiotics-From Metchnikoff to Bioactives. International Dairy Journal, 2008; 18:714-28

Wallace BD, Wang H, Lane KT, Scott JE, Orans J, Koo JS, Venkatesh M, Jobin C, Yeh LA, Mani S, Redinbo MR. Alleviating cancer drug toxicity by inhibiting a bacterial enzyme. Science, 2010; 330:831-835.

Winter SE, Thiennimitr P, Winter MG, Butler BP, Huseby DL, Crawford RW, Russell JM, Bevins CL, Adams LG, Tsolis RM, et al. Gut inflammation provides a respiratory electron acceptor for Salmonella. Nature, 2010; 467:426-429.

Belkaid Y, Hand TW. Role of the Microbiota in Immunity and Inflammation. Cell, 2014; 157(1):121-141

Zhang Y-J, Li S, Gan R-Y, Zhou T, Xu D-P, Li H-B. Impacts of Gut Bacteria on Human Health and Diseases. Int J Mol Sci, 2015; 16:74937519.

Zarate G. Dairy Propionibacteria: Less conventional probiotics to improve the human and animal health. In: Probiotic in Animals. Intech, 2012. Chapter 8:153-202

Zhou L, Ivanov, Spolski R, Min R, Shenderov K, Egawa T, Levy DE, Leonard WJ, Littman DR. IL-6 programs T(H)-17 cell differentiation by promoting sequential engagement of the IL-21 and IL-23 pathways. Nat Immunol, 2007; 8:967-74.

De La Cochetière MF, et al. Effect of antibiotic therapy on human fecal microbiota and the relation to the development of Clostridium difficile. Microb. Ecol, 2008; 56:395-402.

Brandl K, Plitas G, Mihu CN, Ubeda C, Jia T, Fleisher M, Schnabl B, DeMatteo RP, Pamer EG. Vancomycin-resistant enterococci exploit antibiotic-induced innate immune deficits. Nature, 2008; 455:804807.

Wang Q, Yang S, Liu J, Terecskei K, Abraham E, Gombar A. Host-secreted antimicrobial peptide enforces symbiotic selectivity in Medicago truncatula. Proc Natl Acad Sci, 2017; 114:6854-6859.

Chu CM, Yao CT, Chang YT, Chou HL, Chou YC, Chen KH, Terng HJ, Huang CS, Lee CC, Su SL, Liu YC, Lin FG, Wetter T, Chang $\mathrm{CW}$. Gene expression profiling of colorectal tumors and normal mucosa by microarrays meta-analysis using prediction analysis of microarray, artificial neural network, classification, and regression trees. Disease Markers, 2014, 634123:1-11
Viaud S, Saccheri F, Mignot G, Yamazaki T, Daillere R, Hannani D, Enot DP, Pfirschke C, Engblom C, Pittet MJ, Schlitzer A, Ginhoux F, Apetoh L, Chachaty E, Woerther PL, Eberl G, Berard M, Ecobichon C, Clermont D, Bizet C, Gaboriau-Routhiau V, Cerf-Bensussan N, Opolon P, Yessaad N, Vivier E, Ryffel B, Elson CO, Dore J, Kroemer G, Lepage P, Boneca IG, Ghiringhelli F, Zitvogel L. The intestinal microbial modulates the anticancer immune effects of cylcophosphamide. Science, 2013; 342:971-976

Ding S, Chi MM, Scull BP, Rigby R, Schwerbrock NM, Magness S, Jobin C, Lund PK. High-fat diet: bacteria interactions promote intestinal inflammation which precedes andcorrelates with obesity and insulin resistance in mouse. PLoS One, 2010; 5(8):1-13.

Hilderbrandt MA, Hoffmann C, Sherrill-Mix SA, Keilbaugh SA, Hamady M, Chen YY, Knight R, Ahima RS, Bushman F, Wu GD. High-fat diet determines the composition of the murine gut microbiome independently of obesity. Gastroenterology, 2009; 137:1716-24.

Safavi M, Farajian S, Kelishadi R, Mirlohi M, Hashemipour M. The effects of synbiotic supplementation on some cardio-metabolic risk factors in overweight and obese children: A randomized triple-masked controlled trial. Int J Food Sci Nutr, 2013; 64:687-693.

Johnston BC, Ma SSY, Goldenberg JZ, Thorlund k, Vandvik PO, Loeb M, Guyatt GH. Probiotics for the prevention of Clostridium difficileassociated diarrhea: a systematic review and meta-analysis. Ann Intern Med, 2012; 157(12):878-888.

Willing BP, Russel SL, Finlay BB. Shifting the balance: antibiotic effects on host-microbiota mutualism. Nature Reviews Microbiology, 2011; 9:233-243

Morgen CS, Sorensen TI. Obesity: global trends in the prevalence of overweight and obesity. Nat Rev Endocrinol, 2014; 10:513-514.

Videlock EJ, Cremonini F. Meta-analysis: probiotics in antibiotic-associated diarrhoea. Aliment. Pharmacol, Ther. 2012; 35:13551369 .

Gorissen L, Raes K, Weckx S, Dannenberger D, Leroy F, De Vuyst L, De Smet S. Production of conjugated linoleic acid and conjugated linolenic acid isomers by Bifidobacterium species Appl Microbiol Biotechnol. Appl Microbiol Biotechnol, 2010; 87(6):2257-66.

Mozaffarian D, Hao T, Rimm EB, Willett WC, Hu FB. Changes in diet and lifestyle and long-term weight gain in women and men. N Engl J Med, 2011; 364:2392-240.

Solis G, de Los Reyes-Gavilan CG, Fernandez N, Margolles A, Gueimonde M. Establishment and development of lactic acid bacteria and bifidobacteria microbiota in breast-milk and the infant gut. Anaerobe, 2010; $16: 307-310$

Borruel N, Carol M, Casellas F, Antolin M, de Lara F, Espin E, Naval J, Guarner F, Malagelada JR. Increased mucosal tumor necrosis factor alpha production in Corhns disease can be down regulated ex-vivo by probiotic bacteria. Gut, 2002; 51:659-664.

Kidd P. Th1/Th2 balance: the hypothesis, its limitations, and implications for health and disease. Altern Med Rev, 2003; 8:223-246.

Hoarau C, Lagaraine C, Martin I, Velge-Roussel F, Lecranchu Y. Supernatant of Bifidobacterium breve induces dendritic cell maturation, activation, and survival through a Toll-like receptor pathway. J Allergy Clin Immunol, 2006; 117:696-702.

Konstantinov SR, Smidt H, De Vos WM, Bruijns SC, Singh SK, Valence F. S layer protein A of Lactobacillus acidophilus NCFM regulates immature dendritic cell and T cell functions. Proc Natl Acad Sci, 2008; 105:19474-19479.

Ewaschuk JB, Diaz H, Meddings L, Diederichs B, Dmytrash A, Backer J. Secreted bioactive factors from Bifidobacterium infantis enhance epithelial cell barrier function. Am J Physiol Gastrointest Liver Physiol, 2008; 295:G1025-G1034.

How to cite this article:

Mishra P, Mishra SK. Role of Microbial Flora and Probiotics in Host Immune Homeostasis. J App Pharm Sci, 2018; 8(10): 136-149. 